\title{
Optimizing Escherichia coli as a protein expression platform to produce Mycobacterium tuberculosis immunogenic proteins
}

\author{
Luciano Piubelli ${ }^{1,2}$, Manuela Campa ${ }^{1,7}$, Caterina Temporini ${ }^{3}$, Elisa Binda ${ }^{1}$, Francesca Mangione ${ }^{4}$, \\ Massimo Amicosante ${ }^{5,6}$, Marco Terreni ${ }^{3}$, Flavia Marinelli ${ }^{1,2^{*}}$ and Loredano Pollegioni ${ }^{1,2}$
}

\begin{abstract}
Background: A number of valuable candidates as tuberculosis vaccine have been reported, some of which have already entered clinical trials. The new vaccines, especially subunit vaccines, need multiple administrations in order to maintain adequate life-long immune memory: this demands for high production levels and degree of purity.

Results: In this study, TB10.4, Ag85B and a TB10.4-Ag85B chimeric protein (here-after referred as full) - immunodominant antigens of Mycobacterium tuberculosis - were expressed in Escherichia coli and purified to homogeneity. The rational design of expression constructs and optimization of fermentation and purification conditions allowed a marked increase in solubility and yield of the recombinant antigens. Indeed, scaling up of the process guaranteed mass production of all these three antigens (2.5-25 mg of pure protein/L cultivation broth). Quality of produced

soluble proteins was evaluated both by mass spectrometry to assess the purity of final preparations, and by circular dichroism spectroscopy to ascertain the protein conformation. Immunological tests of the different protein products demonstrated that when TB10.4 was fused to Ag85B, the chimeric protein was more immunoreactive than either of the immunogenic protein alone.

Conclusions: We reached the goal of purifying large quantities of soluble antigens effective in generating immunological response against $M$. tuberculosis by a robust, controlled, scalable and economically feasible production process.
\end{abstract}

Keywords: Recombinant antigens, Mycobacterium tuberculosis, Chimeric protein, Protein expression

\section{Background}

Tuberculosis (TB) is one of the leading cause of morbidity and mortality in humans, and it represents a major public health problem in many countries [1,2]. Despite Mycobacterium tuberculosis, the causative agent of TB, being identified by Robert Koch in 1882, major gaps remain in our knowledge of the complex cell life of this pathogen. Designing an effective vaccine against TB is an international research priority since human trials have demonstrated a highly variable protective efficacy of the currently used vaccine Mycobacterium bovis bacillus Calmette and

\footnotetext{
* Correspondence: flavia.marinelli@uninsubria.it

'Department of Biotechnology and Life Sciences, University of Insubria, Varese, Italy

${ }^{2}$ The Protein Factory, Interuniversity Centre Politecnico di Milano, ICRM CNR Milano and University of Insubria, Milan, Italy

Full list of author information is available at the end of the article
}

Guerin (BCG) [2]. BCG is protecting against severe forms of childhood TB, but it is of limited use against adult pulmonary disease and its protective efficacy wanes significantly over a period of $10-15$ years [3,4]. Due to the increasing incidence of multi- and extremedrug-resistant $M$. tuberculosis clinical isolates, chemotherapeutic treatment options are often limited, toxic and of questionable efficacy. An improved second generation vaccine that can act as an efficient prophylactic vaccine and/or a vaccine that can boost immunity in BCG-vaccinated individuals is, therefore, urgently needed [5].

The availability of the $M$. tuberculosis genome sequence and the current efforts to sequence a large number of additional mycobacterial genomes [5] have set the stage for a post-genomics approach to the identification, production and trials of novel antigens. Gene families of

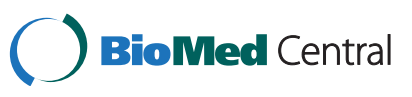


immunodominant proteins have been identified in silico and tested in vivo. Among them, Ag85 complex (Ag85 $\mathrm{A}, \mathrm{B}, \mathrm{C})$, the most abundant protein secreted by $M$. tuberculosis, attracts considerable interest for a new TB vaccine development. Ag85B, a mycolyl transferase, is among the most potent antigen species yet identified, which induces both humoral and cell-mediated immune response in $M$. tuberculosis-infected subjects [6,7]. Another gene family, the esat- 6 one, has been demonstrated to encode several immunodominant proteins that are strongly recognized by the immune systems of different animal models of $\mathrm{TB}$, as well as by $\mathrm{T}$ cells from human beings exposed to M. tuberculosis [8]. TB10.4 is a low molecular mass protein belonging to esat- 6 family. This protein represents a valuable vaccine candidate since it is highly conserved in different M. tuberculosis clinical isolates obtained from different geographical locations and it is strongly recognized by T-cells from BCG-vaccinate donors as well as from TB patients [8]. The subunit vaccine composed of Ag85B-TB10.4 has been also designed and shown to generate a strong, specific immune response in mice. Vaccinating mice with this subunit vaccine induced a level of protection against TB comparable to that produced by BCG and better than that achieved by vaccinating with either of the single proteins [6].

To support further evaluation of $M$. tuberculosis selected antigens and their modified recombinant variants as candidates for the second-generation vaccines against $\mathrm{TB}$, a reliable and robust production process is urgently needed today. Vaccine candidates should be produced in the quantity and quality needed for preclinical and clinical studies. Although it is possible to purify native antigens from $M$. tuberculosis, it is more efficient and safer to express them in an heterologous host such as Escherichia coli and then optimize the recombinant protein production process $[9,10]$. With this approach, molecular engineering may be used to redesign antigens of interest and to combine and fuse two antigens such in the case of the Ag85B-TB10.4 subunit vaccine. Unfortunately until now most of the recombinant antigens currently explored as TB vaccine candidates have been purified in very low amount from $E$. coli, making the production process for large scale use extremely costly. Due to the tendency of incorrect protein folding and aggregation when over-expressed in an heterologous system, these antigens often accumulated in inclusion bodies (IBs), from whom they were recovered by solubilisation with denaturant agents followed by tailored procedures of protein renaturation $[11,12]$. The use and the following removal of large amount of denaturant agents increase the production cost and require additional steps of quality control. In addition, recent data demonstrated that $M$. tuberculosis antigens purified from
IBs do not retain the conformation adopted by the soluble counterparts, raising the question of whether these recombinant proteins keep the same immunogenicity of the native antigens [12].

In this paper, we have adopted different strategies to express recombinant Ag85B, TB10.4 and the fused TB10.4-Ag85B chimeric protein, with the aim of purifying these antigens in a soluble form from E. coli cells. Chemical identity and stability, immunological activity and, last but not least, production feasibility and cost of the produced recombinant proteins have been assessed to sustain their further development as vaccine candidates per se or as a scaffold for further structural modifications. Production and purification processes of these immunogenic proteins have been successfully scaled up from shaken flasks to bench bioreactors.

\section{Results}

Production and purification of Trx-TB10.4 and TB10.4

The synthetic cDNA coding for TB10.4 (GenBank Accession no. CAA17363.1) was optimized to match the codon usage for E. coli expression (see Additional file 1: Figures $\mathrm{S} 1$ and S2). Codon usage optimization was essential since E. coli is a low $\mathrm{G}+\mathrm{C}$ content ( 50\%) Gram-negative bacterium while $M$. tuberculosis is a high $\mathrm{G}+\mathrm{C}(>65 \%)$ Gram-positive actinobacterium. The cDNA was subcloned into pET32b plasmid in frame with nucleotidic sequence coding for thioredoxin (Trx), with a $\mathrm{His}_{6}$-tag sequence and with a sequence recognized by enterokinase (EK) - these sequences are located at the N-terminus of TB10.4 (Figure 1). Trx is a $12 \mathrm{kDa}$ protein that remarkably increases the solubility of fusion proteins [13]. The chimeric Trx-TB10.4 protein (261 amino acids, molecular mass $28.1 \mathrm{kDa}$, Table 1 and Figure 1) was produced in E. coli using BL21(DE3) strains. Basal expression was performed in LB medium, adding $0.1 \mathrm{mM}$ IPTG when $\mathrm{OD}_{600 \mathrm{~nm}}$ reached $0.6-0.8$ and collecting cells after additional 4 hours of growth at $18^{\circ} \mathrm{C}$ : using these conditions, a fairly good amount of chimeric protein was produced as soluble form and about $2 \mathrm{mg} / \mathrm{L}$ of $>85 \%$ pure Trx-TB10.4 was purified after a single-step purification on nickelaffinity chelating column. Optimization of the expression conditions (i.e. growing cells for 16 hours at $18^{\circ} \mathrm{C}$ after IPTG addition) increased significantly the production of the soluble form of the chimeric protein: $12 \mathrm{mg} / \mathrm{L}$ of $>95 \%$ pure Trx-TB10.4 was purified by metal-chelating chromatography (Table 2, see Additional file 2: Figures S3A, B and C). Mass spectrometry (MS) spectrum of the fusion protein reported in Figure 2A confirmed the identity and purity of the fused protein, indicating a molecular mass corresponding to the isoform lacking methionine at the $\mathrm{N}$-terminal.

Complete cleavage of Trx-TB10.4 fusion protein was obtained using $3 \mathrm{U}$ of recombinant enterokinase ( $\mathrm{rEK}$ ) 


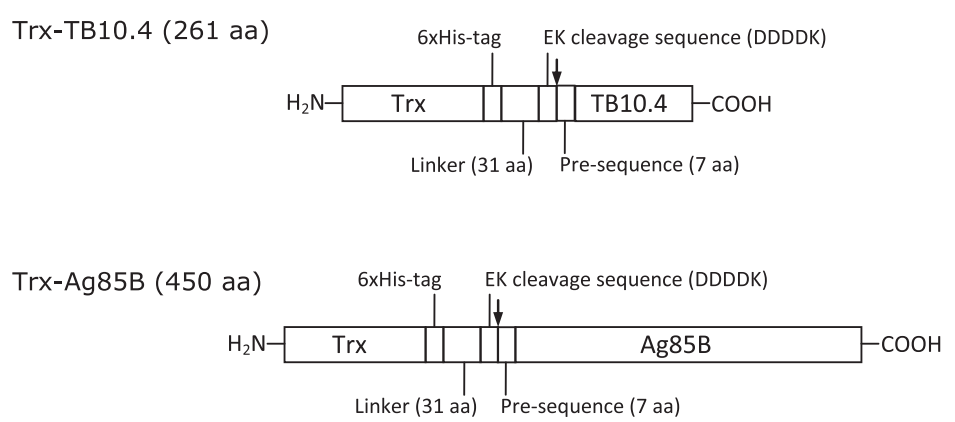

Trx-full (546 aa)

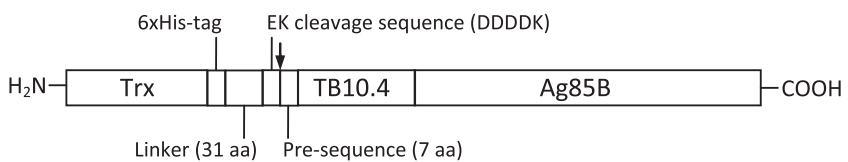

His-full1 (414 aa)

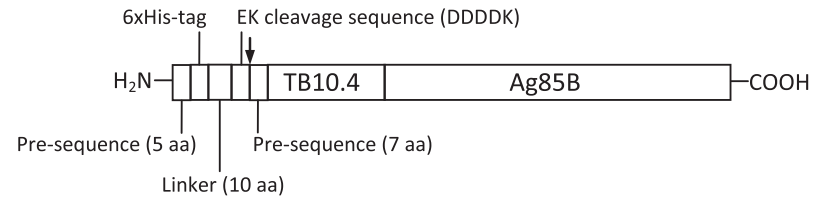

His-full2 (397 aa)

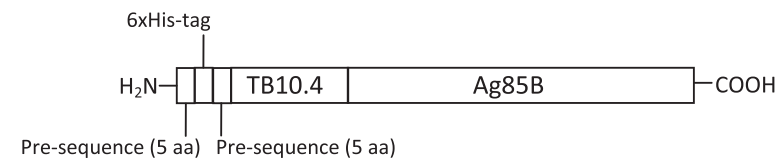

Figure 1 Scheme of the recombinant proteins as produced upon cloning in pET32b (Trx-TB10.4, Trx-Ag85B and Trx-full) or pColdl (His-full1 and His-full2) vectors. Trx: thioredoxin (116 amino acids, aa). The arrow indicates the EK cleavage site. The entire amino acid sequences are reported in the Additional file 1: Figure S2.

Table 1 Chemico-physical parameters of the recombinant proteins as produced upon cloning in $\mathrm{pET} 32 \mathrm{~b}$ or pCold

\begin{tabular}{lccc}
\hline Protein & Length (aa) & Molecular mass (Da) & Theoretical pl \\
\hline Trx-TB10.4 & 261 & $28,133.6$ & 5.06 \\
TB10.4 & 103 & $11,076.3$ & 4.44 \\
Trx-Ag85B & 450 & $48,405.2$ & 5.11 \\
Ag85B & 292 & $31,347.9$ & 4.77 \\
Trx-full & 546 & $58,777.7$ & 4.99 \\
His-full1 & 414 & $44,865.9$ & 5.11 \\
full1 & 388 & $41,720.5$ & 4.71 \\
His-full2 & 397 & $43,060.0$ & 5.53 \\
\hline
\end{tabular}

Theoretical isoelectric point (pl) was calculated by ExPASyBioinformatic Resource Portal (http://www.expasy.org/) using ProtParam tool. per $\mathrm{mg}$ at $20^{\circ} \mathrm{C}$ for 16 hours. The cleaved products $(\operatorname{Trx}$ and TB10.4) were separated by metal-chelating chromatography (see Additional file 2: Figure S3D and E). The expected mature recombinant TB10.4 is a 103 amino acid long protein (Table 1), bearing a seven amino acid residue pre-sequence (AMAISDP) at the N-terminal region originating from the cloning procedure (Figure 1). MS analysis of TB10.4 preparation (Figure 2B) showed the presence of the full-length TB10.4, with an average mass of 11076.0 Da (nominal mass $11076.36 \mathrm{Da}$ ), and an additional product (accounting for ca. $40 \%$ of the total protein) with a calculated average mass of 10776.0 Da. This mass shift $(-300 \mathrm{Da})$ corresponds to the lack of three C-terminal amino acids (WGG) from the mature TB10.4. This secondary cleavage might be due to the AEAAK sequence - resembling the EK consensus sequence (i.e. DDDDK) - that is located just before the three C-terminal amino acids. When the TB10.4 preparation was 
Table 2 Production yield of purified recombinant Trx-TB10.4, Trx-Ag85B (chimeric and single antigens, after proteolytic cleavage), and His-full 2 by $E$. coli cells grown at flask and bioreactor scales

\begin{tabular}{lcccc}
\hline Protein & $\begin{array}{c}\text { Growth } \\
\text { conditions }\end{array}$ & $\begin{array}{c}\text { Biomass at the } \\
\text { harvest time } \\
(\mathbf{g} / \mathbf{L})\end{array}$ & $\begin{array}{c}\text { Pure chimeric } \\
\text { protein }^{\mathbf{b}} \\
\text { (mg/L) }\end{array}$ & $\begin{array}{c}\text { Pure mature } \\
\text { protein } \\
\text { (mg/L) }\end{array}$ \\
\hline Trx-TB10.4 & Flasks & 4.8 & 12 & $4^{c}$ \\
& Bioreactor & 8.5 & 80 & $25^{c}$ \\
Trx-Ag85B & Flasks & 10.5 & 9 & $4.7^{c}$ \\
& Bioreactor & 19.5 & 30 & $16^{c}$ \\
His-full2 & Flasks & 6.5 & $/$ & 0.5 \\
& Bioreactor & 6.5 & $/$ & 2.5
\end{tabular}

a grams of $E$. coli cells (wet weight) per liter of cultivation broth at the harvest time.

${ }^{b}$ milligrams of protein obtained upon purification by nickel-affinity chromatography per liter of cultivation broth.

cmilligrams of protein obtained upon proteolytic cleavage and separation by nickel-affinity chromatography per liter of cultivation broth.

further incubated for 24 hours at $37^{\circ} \mathrm{C}$, additional degradation products appeared, whose formation was instead avoided adding a specific EK inhibitor: this result indicates a persisting proteolytic activity by residual EK not (completely) removed by the chromatography on HiTrap chelating column following the cleavage step (see above). Formation of the truncated form was avoided using an optimized rEK (Tag. Off High Activity rEK) $2 \mathrm{U}$ per $\mathrm{mg}$ of substrate protein, 6 hours of incubation at $25^{\circ} \mathrm{C}$ - and removing rEK using EKapture Agarose (Figure 2C). Pure mature TB10.4 was recovered (Table 2) and its stability at room temperature was checked by MS analysis: following the optimized cleavage procedure, no secondary (truncated) forms were apparent. When the same preparation was further incubated for 24 hours at $37^{\circ} \mathrm{C}$ in the absence of an EK inhibitor ca. $74 \%$ of the mature TB10.4 form was still present (Figure 2D).

\section{Production and purification of Trx-Ag85B and Ag85B}

The synthetic cDNA coding for the mature form (285 amino acids) of Ag85B lacking the region encoding for the $\mathrm{N}$-terminal 40 residues corresponding to the putative signal peptide (UniProtKB/Swiss-Prot Accession no. P0C5B9.1; PDB Accession no. 1F0N_A), also optimized for $E$. coli expression, was subcloned into pET32b plasmid, in frame with nucleotidic sequence coding for Trx, with a $\mathrm{His}_{6}$-tag sequence and with a sequence recognized by $\mathrm{EK}$ - these sequences are located at the $\mathrm{N}$-terminus of Ag85B (Figure 1). The Trx-Ag85B chimeric protein is 450 amino acid long and its molecular mass is $48.4 \mathrm{kDa}$ (Table 1 and Figure 1, see also Additional file 1: Figures S1 and S2). Using the same standard conditions set up for Trx-TB10.4, a very low amount of soluble

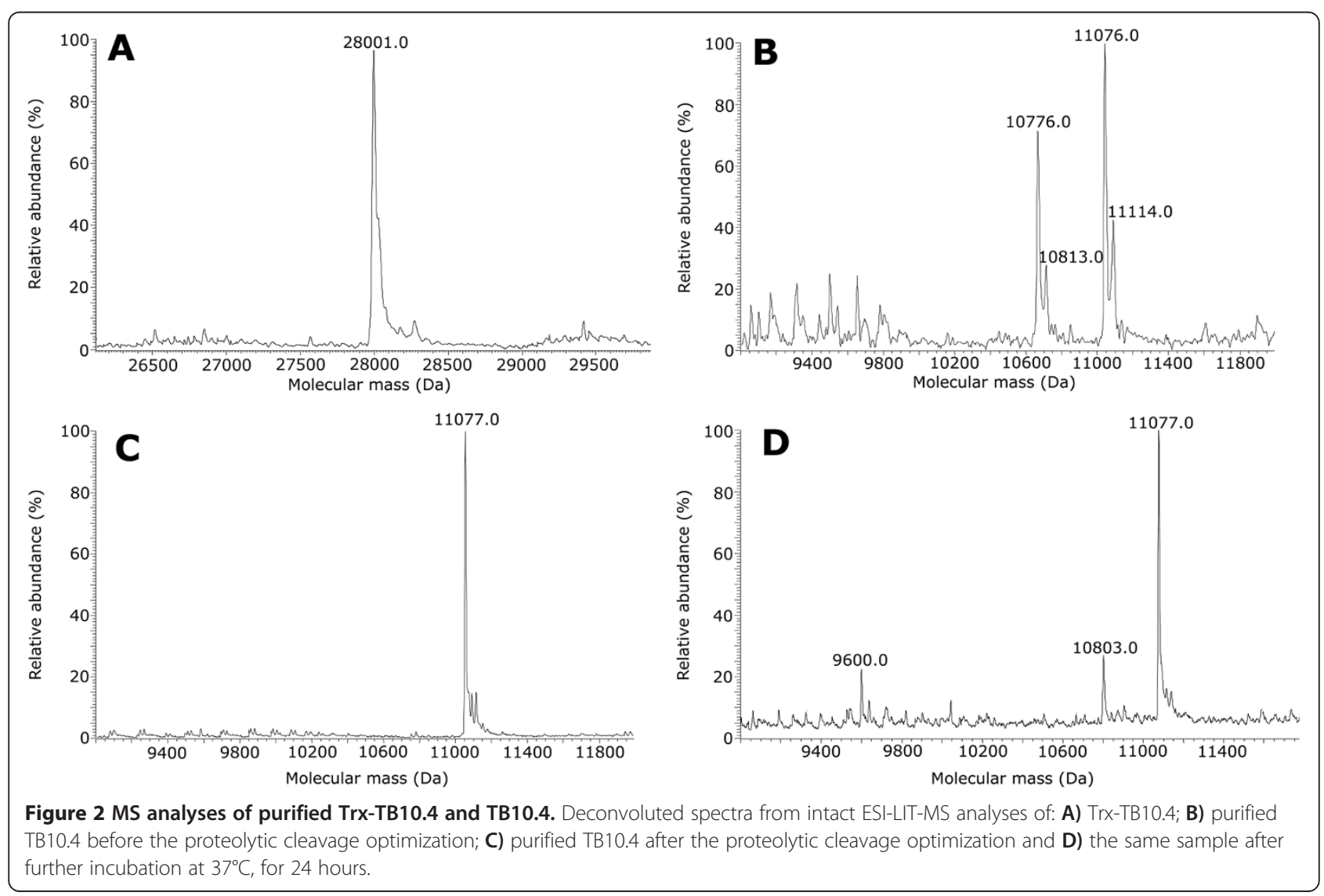


Trx-Ag85B was produced and a low amount of pure protein $(<1 \mathrm{mg} / \mathrm{L})$ was isolated by metal chelating chromatography. In order to improve the amount of protein produced, a number of expression conditions - using different growth media (LB, TB, SB and minimal medium M9), adding 0.1 or $1.0 \mathrm{mM}$ IPTG when $\mathrm{OD}_{600 \mathrm{~nm}}$ reached 0.7, 2 or after overnight growth (saturation condition) were tested. In all cases, following IPTG addition, cells were grown at $18^{\circ} \mathrm{C}$ and collected after 4 hours, and the expression level was assessed by Western blot using anti-His-tag antibody. The largest amount of soluble Trx-Ag85B was obtained growing cells in SB medium and inducing expression with $0.1 \mathrm{mM}$ IPTG at an $\mathrm{OD}_{600 \mathrm{~nm}}=2$ (see Additional file 2: Figure S4). Further improvement was obtained growing cells for additional 16 hours (overnight) after IPTG addition. Using these conditions, ca. $25-30 \%$ of the chimeric protein was soluble (Additional file 2: Figure S5B and C) corresponding to a productivity of $20 \mathrm{mg} / \mathrm{L}: 9 \mathrm{mg} / \mathrm{L}$ of Trx-Ag85B (> 95\% purity degree) were isolated after a single-step purification on nickel-affinity column chromatography (Table 2, see Additional file 2: Figure S5A, B and C). MS spectrum of the fusion protein confirmed its identity and purity (Figure 3A).

Complete maturation of the fusion protein was obtained using $3 \mathrm{U}$ of rEK per $\mathrm{mg}$ of Trx-Ag85B at $20^{\circ} \mathrm{C}$ for 16 hours (Table 2, see Additional file 2: Figure S5D

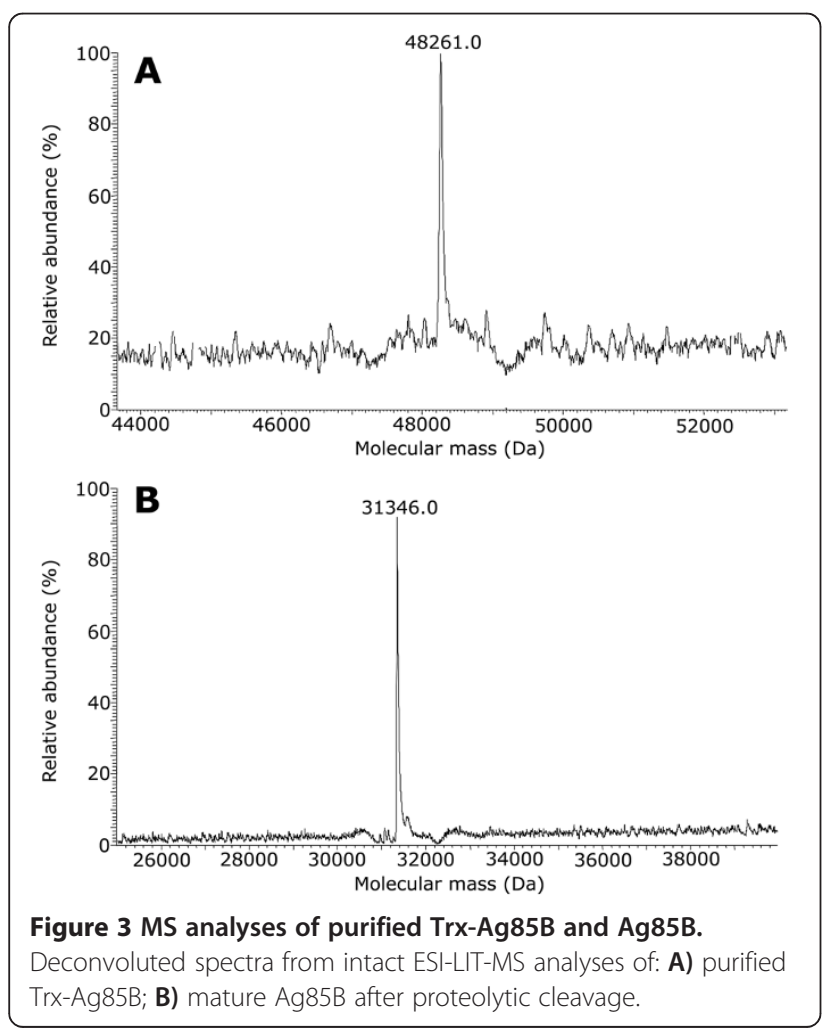

and E). The mature Ag85B obtained by rEK cleavage is a 292 amino acid long protein (molecular mass: $31.3 \mathrm{kDa}$, see Table 1 and Figure 1), bearing at the $\mathrm{N}$-terminal end a pre-sequence (AMAISDP) originating from the cloning procedure. MS analysis confirmed the identity and purity of the mature Ag85B, with a determined mass of 31346.0 Da (nominal mass 31347.9 Da, Figure 3B).

\section{Production and purification of TB10.4-Ag85B (full) protein}

The synthetic cDNA coding for the fusion protein obtained by the combination of the nucleotide sequences of TB10.4 and Ag85B (namely, full protein) was subcloned into pET32b plasmid, in frame with the sequence coding for Trx, with a $\mathrm{His}_{6}$-tag sequence and with a sequence recognized by $\mathrm{rEK}$ (useful to remove Trx). The chimeric protein Trx-TB10.4-Ag85B (Trx-full) is 546 amino acid long (molecular mass is $58.8 \mathrm{kDa}$, Table 1 and Figure 1). Since the aim of this work was to produce soluble antigens, the TB10.4-Ag85B fusion protein was preferred to the Ag85B-TB10.4 version because the latter chimera was never produced in a significant amount as soluble protein [6,12]. The solubility of Trx-TB10.4Ag85B protein was reported to be $>10$-fold increased compared to that of Trx-Ag85B-TB10.4 [12].

Trials for the expression of Trx-full were conducted using the same conditions set up for the single antigenic proteins. Western blot analysis of the produced Trx-full in cell extracts showed that a consistent fraction (80-90\%) of the fusion protein accumulated into the insoluble fraction, being only traces of the protein detectable in the soluble fraction (and together with proteolytic products, data not shown). Co-expression of different chaperon proteins (AraB/DnaK/DnaJ/GrpE or GroES/GroEL/TiG) did not increase the solubility of the fusion protein. Purification of soluble Trx-full yielded less than $1 \mathrm{mg} / \mathrm{L}$, with purity inferior to $50 \%$ (data not shown).

To obtain higher amounts of the full protein as soluble form, the chimeric cDNA was inserted into pColdI plasmid, a system based on low-temperature expression gene (cold shock gene) specifically designed to improve the solubility in E. coli of heterologous proteins [14]. Two different gene constructs were prepared, named His-full1 and His-full2: in both cases, the full protein bears the His-tag at the N-terminus without thioredoxin (Figure 1). His-full1 is a 414 amino acid long protein (molecular mass of $44.9 \mathrm{kDa}$, Table 1 and Figure 1, see also Additional file 1: Figure S2), still bearing at the Nterminal region the sequence recognized by EK. Expression trials for His-full1 were conducted in BL21(DE3) and BL21(DE3)pLysS E. coli strains, growing cells in LB, $\mathrm{TB}$ or $\mathrm{SB}$ media at $37^{\circ} \mathrm{C}$, adding $1.0 \mathrm{mM}$ IPTG when cells reached early/middle exponential growth phase $\left(\mathrm{OD}_{600 \mathrm{~nm}}=0.6-0.7\right.$ for $\mathrm{LB}$ and 1.2-1.5 for TB and $\left.\mathrm{SB}\right)$ or middle/late exponential growth phase $\left(\mathrm{OD}_{600 \mathrm{~nm}}=1.2\right.$ - 
1.5 for $\mathrm{LB}$ and 4-5 for $\mathrm{TB}$ and $\mathrm{SB}$ ). Cells were then grown for additional 20 hours at $15^{\circ} \mathrm{C}$ prior harvesting. Western blot analysis of cells extracts showed the major part of the expressed His-full1 (ca. 80\%) accumulated as IBs. A maximum yield of $1.3 \mathrm{mg} / \mathrm{L}$ of His-full1 with $c a$. $85 \%$ purity was obtained after a single-step purification (on HiTrap Chelating chromatography) from cells grown in $\mathrm{TB}$ medium added with $5 \mathrm{~g} / \mathrm{L}$ of $\mathrm{NaCl}$ and by adding further $25 \mathrm{~g} / \mathrm{L}$ of $\mathrm{NaCl}$ at the moment of induction with IPTG, according to a protocol previously developed in our lab [15] (data not shown). Incubation of purified His-full1 with EK in the same condition used for TrxAg85B (3 U/mg His-full1, for 16 hours at $20^{\circ} \mathrm{C}$ ) yielded a consistent amount of proteolytic products, indicating a high sensitivity to proteolysis of the chimeric protein (not shown).

In order to eliminate the EK cleavage step and to reduce the length of the additional sequence at the $\mathrm{N}$ terminal end of the chimeric protein, site-directed mutagenesis of the full cDNA introduced a NdeI restriction site allowing its cloning in pColdI plasmid using NdeI and EcoRI restriction sites (Figure 1). By this strategy, a 397 amino acid long protein (namely His-full2, molecular mass: $43.06 \mathrm{kDa}$, Table 1 and Figure 1) was designed. His-full 2 contains 16 additional amino acids including the $\mathrm{His}_{6}$-tag sequence (MNHKVHHHHHHIEGRH, see Additional file 2: Figure S2) at the N-terminal end vs. the 33 amino acids present in the previous TB10.4Ag85B chimeric proteins.

Expression trials carried out on His-full 2 showed that, similarly to Trx-Ag85B (see the paragraph above), the best expression conditions were based on the use of SB medium and induction with $0.1 \mathrm{mM}$ IPTG at $\mathrm{OD}_{600 \mathrm{~nm}}=2$. An increase in the production of the recombinant protein was obtained using $\mathrm{NaCl}$ in the medium $(10 \mathrm{~g} / \mathrm{L})$ and by adding further $25 \mathrm{~g} / \mathrm{L}$ of $\mathrm{NaCl}$ simultaneously to IPTG (not shown). As reported in Table 2 and explained below, His-full2 production increased significantly when scaledup to a $3 \mathrm{~L}$ bioreactor. However, the major part of the fusion protein again accumulated as IBs (see Additional file 2: Figure $\mathrm{S} 6 \mathrm{~B}$ and $\mathrm{C}$, that refer to cells produced at bioreactor scale). About $0.5 \mathrm{mg} / \mathrm{L}$ of His-full 2 with a purity of $c a .90 \%$ was obtained after the HiTrap Chelating chromatography performed under optimized conditions (linear gradient from 100 to $250 \mathrm{mM}$ imidazole in 3column volumes, see Additional file 2: Figure S6A and C). Despite the lower yield than for the His-full1, this second chimeric protein had the advantage to skip the EK cleavage step. MALDI-TOF/TOF MS spectrum of the chimeric protein is given in Figure 4. The two principal ions observed correspond to the doubly charged natrium adduct (at $21557.68 \mathrm{~m} / z$ ) and to the doubly charged natrium/ synapinic acid adduct $(21668.3 \mathrm{~m} / z)$ of the His-full 2 protein, confirming its identity.

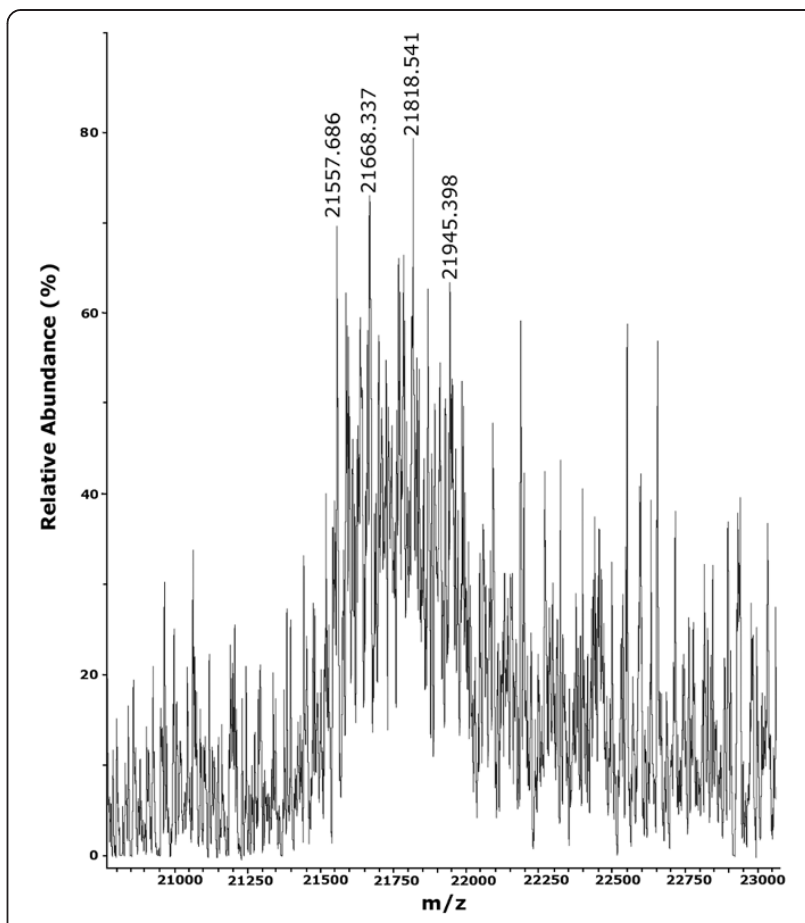

Figure 4 MALDI-TOF/TOF mass spectrum of the doubly-charged protein His-full2. Two principal isoforms can be observed, corresponding to the natrium adduct (at $21557.68 \mathrm{~m} / \mathrm{z}$ ) and to the natrium/synapinic acid adduct $(21668.3 \mathrm{~m} / \mathrm{z})$.

\section{Scaling up of protein antigen production}

After optimization at the shaken flask-scale, processes and production media were scaled up in $3 \mathrm{~L}$ bioreactor. As shown by the parameters controlled on line $\left(\mathrm{dO}_{2}\right.$ and $\mathrm{pH}$ ) and by densitometric analysis of cell growth during batch cultivation (Figure 5), the growth of recombinant E. coli BL21(DE3) cells holding the pColdI-His-full2 was faster than those transformed by pET32b-Trx-TB10.4 and pET32b-Trx-Ag85B, even if a lower temperature was adopted after induction of protein expression $\left(15^{\circ} \mathrm{C}\right.$ for His-full 2 production vs. $18^{\circ} \mathrm{C}$ for $\operatorname{Trx}-\mathrm{TB} 10.4$ and Trx-Ag85B). In 6 hours from inoculum, maximum biomass was achieved and $\mathrm{dO}_{2}$ was completely depleted in cells producing His-full2. In Trx-Ag85B production, oxygen depletion occurred after 8 hours from inoculum and the phase of oxygen limitation lasted for further ten hours. E. coli Trx-TB10.4-producing cells showed a similar time course of oxygen consumption, but the levels of $\mathrm{dO}_{2}$ never decreased below $50 \%$ of saturation, indicating a minor respiratory activity; growth of the culture was slower and reached a lower level of biomass production (in wet weight: 19.5 and $8.5 \mathrm{~g} / \mathrm{L}$ were recovered after 24 hours from cells producing Trx-Ag85B or TrxTB10.4, respectively, see Table 2). For both Trx-Ag85B or Trx-TB10.4 producing cells, after an initial slight decrease, $\mathrm{pH}$ tended to alkalinization in the following fermentation phase. In cells producing His-full2, a 

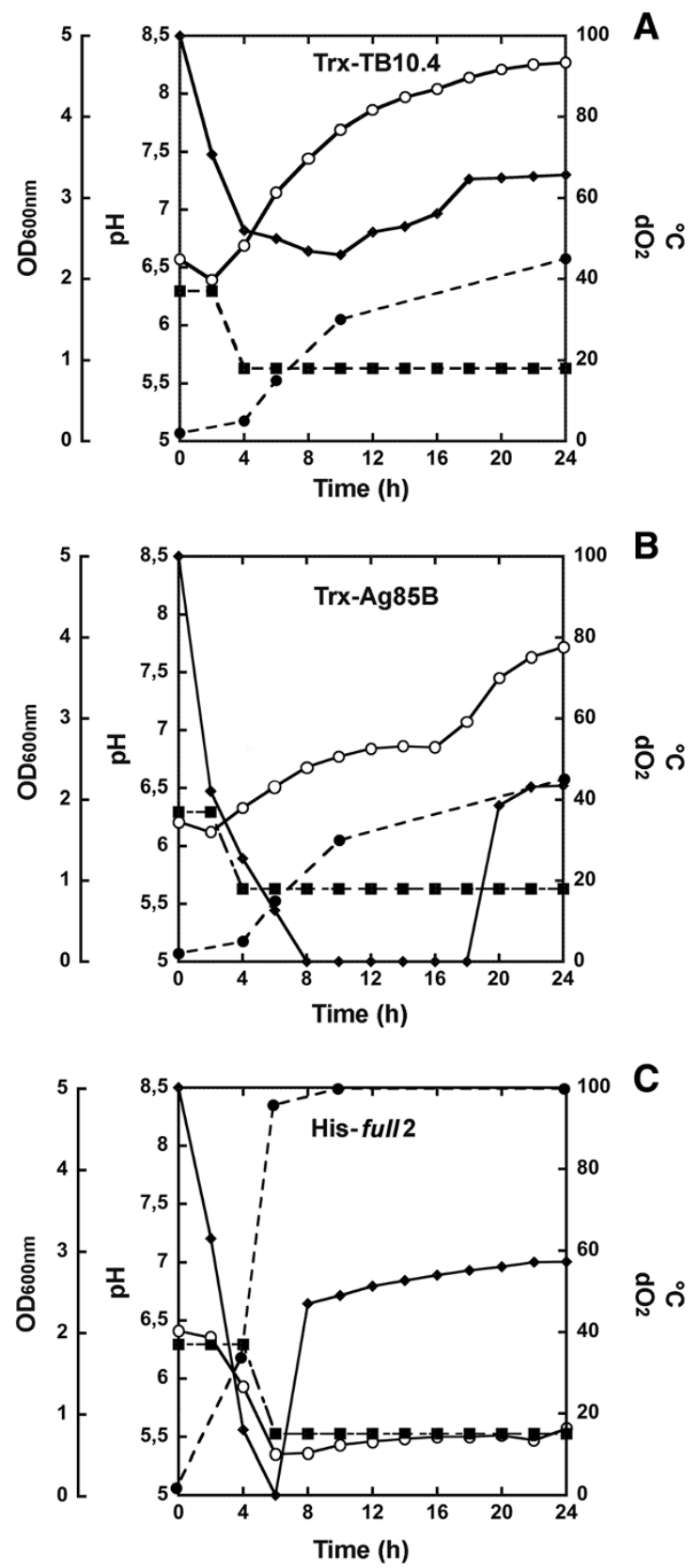

Figure 5 Time course of $\mathrm{pH}\left(\circ\right.$, solid line), $\mathrm{dO}_{2}(\diamond$, solid line) and $\mathrm{OD}_{600 \mathrm{~nm}}(\bullet$, dashed line) in $3 \mathrm{~L}$ batch cultivation trials of recombinant $E$. coli $\mathrm{BL} 21$ (DE3) cells producing $M$. tuberculosis immunogenic proteins. A) E. coli BL21(DE3) cells containing pET32b-Trx-TB10.4 plasmid and grown in LB medium. B) E. coli BL21 (DE3) cells containing pET32b-Trx-Ag85B plasmid and grown in SB medium. C) E. coli BL21(DE3) cells containing pColdl-His-full2 and growing in $\mathrm{SB} / \mathrm{NaCl}$ medium. Temperature ( $\mathbf{n}$, dashed line) was kept constant at $37^{\circ} \mathrm{C}$ before IPTG addition and then reduced to $18^{\circ} \mathrm{C}$ for Trx-TB10.4 and Trx-Ag85B production, and at $15^{\circ} \mathrm{C}$ for His-full 2 production, until harvest. The induction of protein expression was done at $\mathrm{OD}_{600 \mathrm{~nm}}=0.8$ with $0.1 \mathrm{mM}$ IPTG for Trx-TB10.4, at $\mathrm{OD}_{600 \mathrm{~nm}}=2$ with $0.1 \mathrm{mM}$ IPTG for Trx-Ag85B, and at $\mathrm{OD}_{600 \mathrm{~nm}}=2$ with $0.1 \mathrm{mM}$ IPTG for His-full2. Biomass (wet weight) collected at the harvest time was 8.5 g/L for Trx-TB10.4, 19.5 g/L for Trx-Ag85B and 6.5 g/L for His-full2. marked acidification of medium and a rapid re-increase in oxygen level after the initial sharp reduction occurred, probably reflecting a stress status arresting cell proliferation after IPTG addition and growth temperature reduction. Notwithstanding the higher $\mathrm{OD}_{600 \mathrm{~nm}}$ of pColdI-His-full2 containing cells, final biomass was only $6.5 \mathrm{~g} / \mathrm{L}$ in wet weight (Table 2).

Table 2 shows that recombinant $E$. coli cells produced more biomass in the stirred bioreactors than in the shaken flasks, due to the better oxygen distribution in the larger scale system which sustains higher density cultivation. Application of the same protocols of metalchelating chromatography described above to purify Trx-Ag85B, Trx-TB10.4 or His-full2 gave a significantly increased purification yield from biomass generated in bioreactor than from shaken flasks: $9.4 \mathrm{mg}$ pure TrxTB10.4, $1.5 \mathrm{mg}$ pure Trx-Ag85B and $0.38 \mathrm{mg}$ pure Hisfull2 per gram of biomass were achieved at bioreactor scale compared to figures of $2.5 \mathrm{mg}$ Trx-TB10.4, $0.85 \mathrm{mg}$ Trx-Ag85B and $0.076 \mathrm{mg}$ His-full 2 per gram of biomass obtained at flask-scale. These data indicate a beneficial effect of scaling up on both the volumetric productivity ( $\mathrm{mg}$ of protein per liter of cultivation broth) and the specific productivity (mg of protein per gram of biomass). In the case of His-full2, protein purification was feasible only at the bioreactor scale, due to low specific productivity of cells grown in flasks: the soluble form of His-full 2 increased from 5 to $\mathrm{ca}$. $15 \%$ of the total expressed chimeric protein shifting from flasks to bioreactor. In the case of Trx-TB10.4 and Trx-Ag85B, the step of EK digestion and mature protein recovery was not affected by the scaling up, being of about one third for TB10.4 and 50\% for Ag85B independently if biomass was generated in flasks or in bioreactors. Identity of the fused and mature antigens was confirmed by MS analyses (spectra overlap with those reported in Figure 2A and $\mathrm{C}$, Figure $3 \mathrm{~A}$ and $\mathrm{B}$, and Figure 4).

\section{Biochemical and immunological characterization of the protein antigens}

The quality of the recombinant antigenic proteins was assessed in terms of purity by SDS-PAGE (Additional file 2: Figure S7) and MS analyses (see above) and in terms of protein conformation by circular dichroism (CD) spectroscopy. The secondary structure of pure Ag85B (as determined by the far-UV CD spectra reported in Figure 6A) is composed of both $\alpha$-helices and $\beta$ sheets (ca. 26 and $23 \%$ as estimated by k2D2 software vs. 37 and $20 \%$ from the crystal structure, pdb code $1 \mathrm{~F} 0 \mathrm{~N}$ ), while for TB10.4 the signal for $\alpha$-helices only is apparent, in good agreement with the known 3D structure (55\% $\alpha$-helix content, pdb code $1 \mathrm{~F} 0 \mathrm{~N})$ and previous analyses [12]. Similarly, the signal for the tertiary structure significantly differs for the two $M$. tuberculosis antigens, 

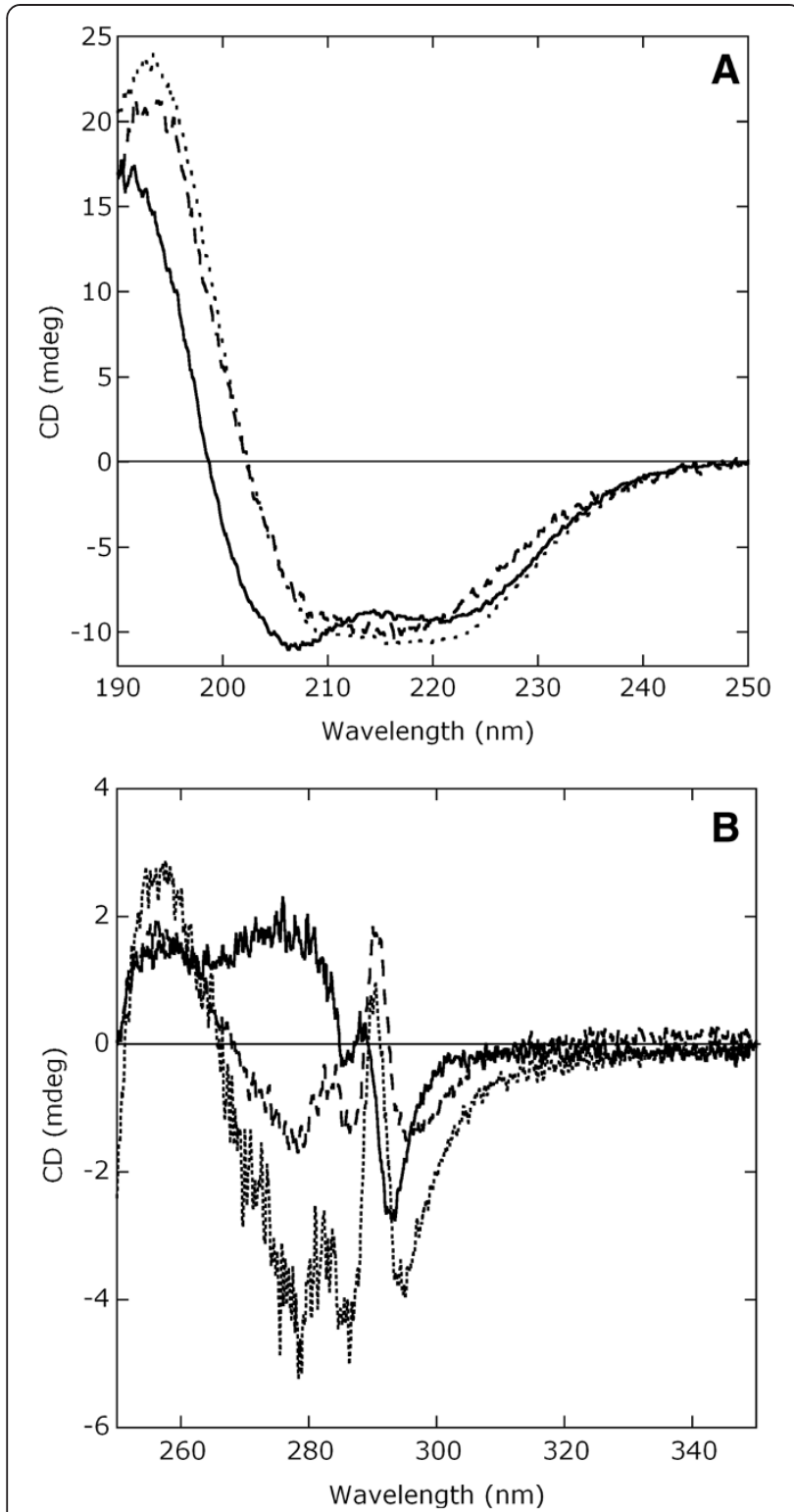

Figure 6 CD spectra of TB10.4 (continuous line), Ag85B (dashed line) and His-full2 (dotted line). A) Far-UV CD spectra (protein concentration: $0.1 \mathrm{mg} / \mathrm{mL}$ ). B) Near-UV CD spectra (protein concentrations: $0.45,0.35$ and $0.85 \mathrm{mg} / \mathrm{mL}$ for TB10.4, Ag85B and His-full2, respectively). All spectra were collected in $10 \mathrm{mM}$ ammonium acetate, $\mathrm{pH}$ 7, at $15^{\circ} \mathrm{C}$.

see Figure 6B. The near- and far-UV spectra of His-full 2 resemble those of Ag85B, according to the fact that Ag85B molecular mass is 3-fold higher than that of TB10.4 (Table 1). All together, spectral analyses indicate the acquisition of a well defined protein conformation for all the recombinant soluble antigenic proteins.

Immunological activity of the recombinant proteins was then assessed by the capability of the proteins to be recognised as antigen by sera (ELISA) or T cells (ELISPOT) of active-TB patients. In a first set of ELISA tests, variable concentrations of the antigens $(100,200$ and $400 \mathrm{ng}$ ) were adsorbed and tested with TB sera at 1:100 dilution. For the Ag85B and the His-full2 proteins, a dose dependent reactivity of TB sera vs. the concentration of the antigen adsorbed on the ELISA plate was observed (Figure 7). On the contrary, almost no reactivity was observed for the TB10.4 protein, in agreement with previous studies [6-8]. Furthermore, in order to assess the specificity of the observed reactivity against the M. tuberculosis recombinant Ag85B and His-full2 protein antigens, antibody titre was determined for each control and active-TB serum by end final point dilution test. As shown in Additional file 3: Figure S8, TB sera present a significant higher antibody titre (median 600) than controls (median 100, $\mathrm{p}<0.001$ ) for the Ag85B protein antigen. Similar results were obtained with the chimeric His-full 2 protein (TB patients median titre 1200 , controls median titre 200, $\mathrm{p}<0.001$ ). These data were further confirmed by analysing the single control and active-TB sera reactivity at 1:200 dilution, as reported in Additional file 3: Figure S9.

Figure 8 shows the results of the T-cell reactivity observed in active TB-patients and healthy controls. Control and active-TB subjects presented a similar T-cell response capability for the Staphylococcus aureus Enterotoxin B (SEB) superantigen used as positive control. For all of the M. tuberculosis recombinant proteins tested, a significant higher number of IFN- $\gamma$ producing effector T-cells were observed in active-TB patients

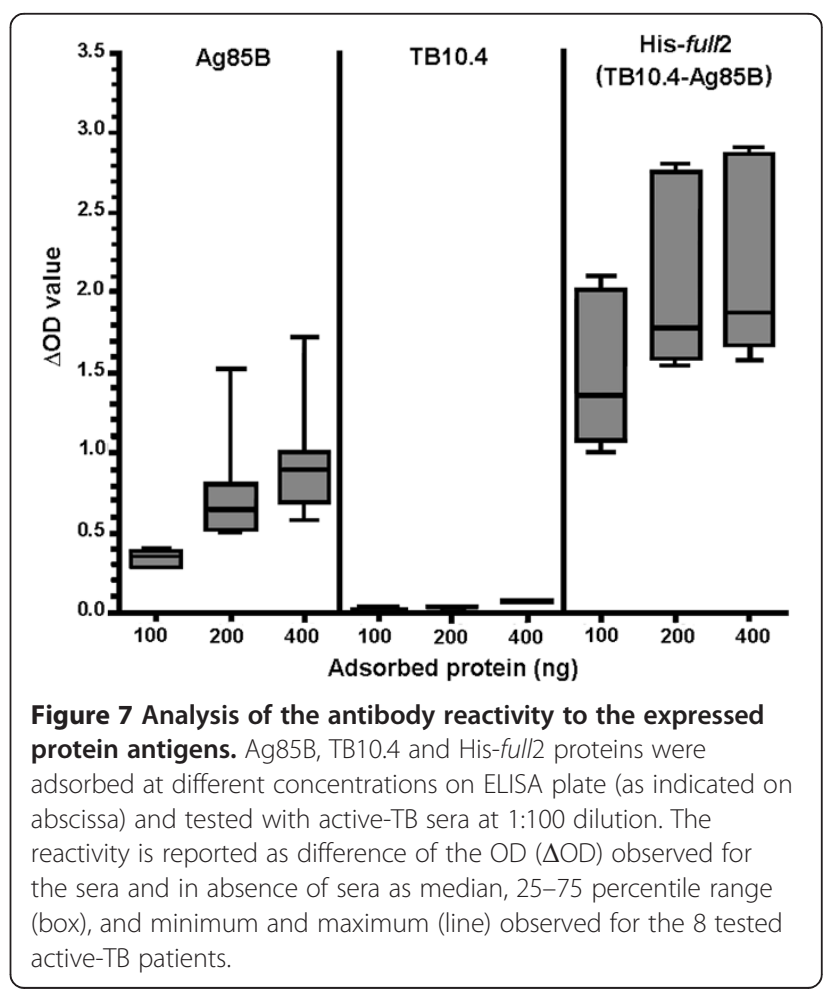




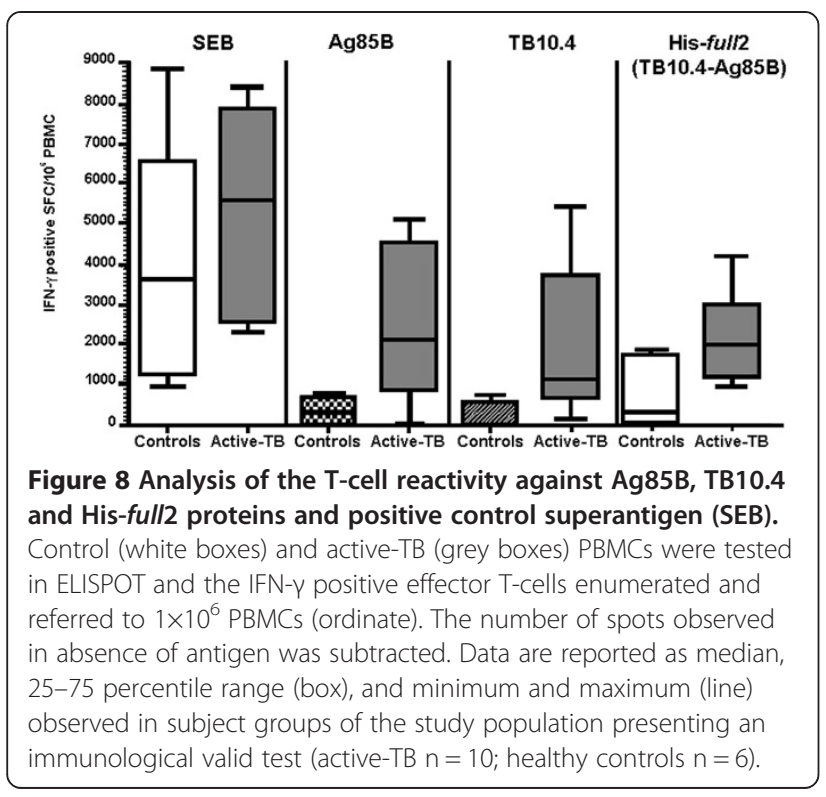

compared to MTB-unexposed controls -Ag85B: controls $312 \pm 363$ (mean \pm std) spots/million peripheral blood mononuclear cells (PBMCs), active-TB $2361 \pm 1863$; $\mathrm{p}<0.0001$; TB10.4: controls 184 \pm 209 , active-TB $2009 \pm 1901 ; \mathrm{p}<0.0001$; His-full2: controls $701 \pm$ 859 , active-TB $22183 \pm 1173 ; \mathrm{p}=0.0381$ - confirming that the cell mediated immune response is effectively triggered by the antigens produced during this study.

\section{Discussion}

A number of interlinking cells and mechanisms are involved in the immune response following $M$. tuberculosis infection. Delivering effective hits to infected target cells represents the way to push the host response to control infection and, possibly, to eradicate bacteria. At present, the development of new TB vaccines follows two main approaches: a) replacing BCG by either improved recombinant BCG or by genetically attenuated M. tuberculosis; b) developing subunit vaccines mostly based on recombinant proteins. In past years, significant progress has been made in producing recombinant antigenic proteins, mostly fusion proteins that combine immunodominant antigens of M. tuberculosis, e.g., the Hybrid 1 fusion protein which consists of Ag85B fused to ESAT6, or Hyvac 4 consisting of Ag85B fused to the antigen TB10.4 [16]. Our aim is to produce well-known $M$. tuberculosis antigens with a native-like structure in order to preserve conformational epitopes in addition to the sequential ones. The importance of native-like structure has been made apparent by the structural vaccinology approach, in which the three-dimensional structural information is used to design novel and improved vaccine antigens. As stated by [17]: "We now routinely determine structures of vaccine antigens as a central task in vaccine optimization. The essential insights that antibody epitopes are conformational, extended protein surfaces and that short, floppy peptides rarely elicit protective antibodies are essential for selecting vaccine research strategies that have a high probability of success".

In the present study, solubility enhancement by Nterminal thioredoxin fusion and/or by optimization of fermentation conditions was investigated for the recombinant antigens Ag85B, TB10.4 and full (TB10.4-Ag85B). Protein over-expression in $E$. coli frequently leads to the formation of IBs; obtaining proteins from the IBs has several drawbacks. Despite these disadvantages, the recombinant $M$. tuberculosis antigens Ag85B [18], TB10.4 [19], and Ag85B-TB10.4 [6] have been previously purified from IBs and formulated into subunit vaccines although their immunogenicity was not the same as for the corresponding native antigens or soluble counterparts. A comparison was recently carried out for TB10.4 and TB10.4-Ag85B proteins [12] and, interestingly, resolubilized TB10.4-Ag85B purified from IBs did not recover the conformation adopted by its counterpart purified from the soluble fraction, but it seemed to adopt an intermediate conformation. In order to preserve native conformation, we produced the three antigens as soluble proteins. The overall yields hereby achieved favourably compare with the values reported in literature: 5 and $1 \mathrm{mg}$ of mature Ag85B and TB10.4-Ag85B per liter of cultivation broth were previously produced in soluble form [12] vs. 16 and $2.5 \mathrm{mg} / \mathrm{L}$ obtained in our conditions (see Table 2); to our knowledge, literature data concerning the production of mature TB10.4 as soluble protein (vs. $25 \mathrm{mg} / \mathrm{L}$ with our procedure) were not reported.

Circular dichroism spectroscopy was used to study secondary and tertiary protein structure. Soluble Ag85B and His-full2 proteins have similar CD spectra. They closely resemble those obtained previously for soluble antigens and distinguished from TB10.4-Ag85B purified from IBs [12]. Our procedure based on the isolation of the proteins from the soluble fraction avoided the folding drawbacks encountered when the TB10.4-Ag85B chimeric protein was re-solubilized from IBs [12].

The produced recombinant proteins presented an appropriate immunogenicity as for the capability to be recognised either by antibodies and T-cells of active-TB patients. Interestingly, when TB10.4 was fused to Ag85B, it presented a stronger immune-reactivity respect the sum of the single proteins (see end final point dilution test in Additional file 3), likely due to a better accessibility of the antigen B-cell epitope recognised by the TBpatient antibody. A similar result was reported earlier [6] also showing that TB10.4 distinguished from ESAT-6, which appeared to be subdominant when fused to Ag85B. Although less apparent, a similar result was also 
achieved for the T-cell reactivity test (Figure 8). All together, the fusion of TB10.4 with Ag85B did not decrease the immunogenicity of either TB10.4 or Ag85B and has a beneficial effect on the immunogenicity of TB10.4.

\section{Conclusions}

In conclusion, the main purpose of this study to purify large quantities of soluble antigens effective in immunological response against $M$. tuberculosis was reached by the rational design of the expression constructs and the optimization of fermentation conditions for $E$. coli recombinant strains. The set up of a controlled, scalable, robust and economically feasible production process (current cost of antigenic protein production at the lab scale is $50-100 € / \mathrm{mg}$, whereas Ag85B is commercially available at $\geq 1800 € / \mathrm{mg}$ ) is important for supporting research and development of novel vaccine candidates to prevent and/or treat tuberculosis.

\section{Methods \\ Design, synthesis and cloning of cDNA coding for antigenic proteins}

Synthetic cDNAs coding for TB10.4 and Ag85B antigenic proteins were designed in silico by back translation of the amino acid sequences reported in the database (TB10.4: GenBank Accession no. CAA17363.1; Ag85B: UniProtKB/Swiss-Prot Accession no. P0C5B9.1). A third cDNA, in which the nucleotide sequence coding for TB10.4 is upstream to the sequence coding for Ag85B (full cDNA) was also designed. All synthetic cDNAs were produced by Eurofins Medigenomix $\mathrm{GmbH}$ (Ebersberg, Germany), after optimization of the nucleotidic sequences for expression in E. coli (see Additional file 2: Figure S1). The three synthetic genes were cloned into pET32b using $B a m \mathrm{HI}$ and EcoRI restriction sites. By this cloning strategy, the genes were fused with thioredoxin (Trx) encoding gene and tagged by an $\mathrm{His}_{6}$-tag. Two additional constructs of the full cDNA were also produced. To prepare His-full 1 form, the full cDNA was extracted from pET32b plasmid using KpnI and EcoRI restriction sites and cloned into pColdI plasmid (TaKaRa Bio Inc., Otsu, Japan). For the production of His-full2 form, site-directed mutagenesis was carried out on the full cDNA using the QuikChange II Site-Directed Mutagenesis Kit (Agilent Technologies, Santa Clara, CA, USA), to insert a NdeI restriction site at the $5^{\prime}$ of the full cDNA, including the triplet coding for the initial methionine. The following mutagenesis primers were used: 5'GCCATGAGCTCGGATCATATGAGCCA GATCATG3'; 5'CATGATCTGGCTCATATGATCCGAG CTCATGGC3' (mutated bases are in italics). The presence of the desired mutation was confirmed by automated DNA sequencing. The mutated cDNA was then cloned into pColdI plasmid using NdeI and EcoRI restriction sites. The gene sequences are reported in Figure 1.

\section{Strain and growth conditions}

For protein expression, all plasmids were transferred to the E. coli hosts BL21(DE3) and BL21(DE3)pLysS. The following media were used: M9/glucose $\left(6.78 \mathrm{~g} / \mathrm{L} \mathrm{Na}_{2} \mathrm{HPO}_{4}\right.$, $3 \mathrm{~g} / \mathrm{L} \mathrm{KH}_{2} \mathrm{PO}_{4}, 1 \mathrm{~g} / \mathrm{L} \mathrm{NH} \mathrm{Nl}_{4} \mathrm{Cl} 0.5 \mathrm{~g} / \mathrm{L} \mathrm{NaCl}, 0.1 \mathrm{mM} \mathrm{CaCl}_{2}$, $2 \mathrm{mM} \mathrm{MgSO}_{4}, 10 \mathrm{~g} / \mathrm{L}$ glucose); Luria-Bertani (LB, $10 \mathrm{~g} / \mathrm{L}$ bacto-tryptone, $5 \mathrm{~g} / \mathrm{L}$ yeast extract, $5 \mathrm{~g} / \mathrm{L} \mathrm{NaCl}$ ); Terrific Broth (TB, $12 \mathrm{~g} / \mathrm{L}$ bacto-tryptone, $24 \mathrm{~g} / \mathrm{L}$ yeast extract, $8 \mathrm{~mL} / \mathrm{L}$ glycerol, $\left.2.2 \mathrm{~g} / \mathrm{L} \quad \mathrm{KH}_{2} \mathrm{PO}_{4}, 9.4 \mathrm{~g} / \mathrm{L} \quad \mathrm{K}_{2} \mathrm{HPO}_{4}\right)$; Terrific Broth/ $\mathrm{NaCl}$ (TB, $12 \mathrm{~g} / \mathrm{L}$ bacto-tryptone, $24 \mathrm{~g} / \mathrm{L}$ yeast extract, $8 \mathrm{~mL} / \mathrm{L}$ glycerol, $2.2 \mathrm{~g} / \mathrm{L} \mathrm{KH}_{2} \mathrm{PO}_{4}, 9.4 \mathrm{~g} / \mathrm{L}$ $\mathrm{K}_{2} \mathrm{HPO}_{4}, 5 \mathrm{~g} / \mathrm{L} \mathrm{NaCl}$ ); Super Broth (SB, $32 \mathrm{~g} / \mathrm{L}$ bactotryptone, $20 \mathrm{~g} / \mathrm{L}$ yeast extract, $5 \mathrm{~g} / \mathrm{L} \mathrm{NaCl}$ ); Super Broth/ $\mathrm{NaCl}(\mathrm{SB} / \mathrm{NaCl}, 32 \mathrm{~g} / \mathrm{L}$ bacto-tryptone, $20 \mathrm{~g} / \mathrm{L}$ yeast extract, $10 \mathrm{~g} / \mathrm{L} \mathrm{NaCl})[15,20]$. Starter cultures were prepared from a single colony of $E$. coli carrying the recombinant plasmid, employing the same medium used for protein expression containing ampicillin $(100 \mu \mathrm{g} / \mathrm{mL}$, final concentration) and, in the case of BL21(DE3)pLysS strain, also chloramphenicol (34 $\mu \mathrm{g} / \mathrm{mL}$, final concentration). Cultures were grown overnight under vigorous shaking at $37^{\circ} \mathrm{C}$. For chaperone co-expression, BL21(DE3) E. coli cells were co-transformed with pKJE7 (coding for AraB, DnaK, DnaJ and GrpE) or with pG-Tf2 (coding for GroES, GroEL and TiG) plasmids (Chaperone Plasmid Set, TaKaRa Bio Inc., Otsu, Japan), adding chloramphenicol (30 $\mu \mathrm{g} / \mathrm{mL}$, final concentration) to the growth medium. Expression of the chaperone proteins was induced by adding $1 \mathrm{mg} / \mathrm{mL}$ L-arabinose (for pKJE7) or with $2 \mathrm{ng} / \mathrm{mL}$ tetracyclin (for pG-Tf2), according to the manufacturer's instructions. Protein production trials were carried out in $500 \mathrm{~mL}$ or $2 \mathrm{~L}$ baffled Erlenmeyer flasks containing $80 \mathrm{~mL}$ or $500 \mathrm{~mL}$ of each medium inoculated with the starter cultures (initial $\left.\mathrm{OD}_{600 \mathrm{~nm}}=0.1\right)$. Cells were grown at $37^{\circ} \mathrm{C}$ with shaking (150 rpm) until protein expression was induced by adding IPTG: cells were then grown at 15 or $18^{\circ} \mathrm{C}$ until harvesting. Collected cells were washed with STE buffer and stored at $-20^{\circ} \mathrm{C}$.

\section{$3 \mathrm{~L}$ bioreactor cultivations}

SB for E. coli BL21(DE3) cells containing the pET32bTrx-Ag85B plasmid, LB for those transformed with pET32b-Trx-TB10.4 plasmid and $\mathrm{SB} / \mathrm{NaCl}$ for those transformed with pColdI-His-full2 plasmid were used as production media in $2 \mathrm{~L}$ working volume P-100 Applikon $3 \mathrm{~L}$ glass reactor (height $25 \mathrm{~cm}$, diameter $13 \mathrm{~cm}$ ) equipped with a AD1030 Biocontroller and AD1032 motor $[20,21]$. Cultivations in bioreactor were conducted in batch-mode at $37^{\circ} \mathrm{C}, 500 \mathrm{rpm}$ stirring (corresponding to $1.17 \mathrm{~m} / \mathrm{s}$ of tip speed) and $2 \mathrm{~L} / \mathrm{min}$ aeration rate. Foam production was controlled by the addition of Hodag 
antifoam through an antifoam sensor. Starter cultures were grown overnight in $\mathrm{SB}, \mathrm{LB}$ or $\mathrm{SB} / \mathrm{NaCl}$ medium and diluted up to an initial $\mathrm{OD}_{600 \mathrm{~nm}}$ of 0.1 . For pET32b-TrxAg85B and pET32b-Trx-TB10.4 recombinant cells, after $2-4$ hours of growth (corresponding to an $\mathrm{OD}_{600 \mathrm{~nm}}$ of 2 for the previous and of 0.8 for the latter), $0.1 \mathrm{mM}$ IPTG was added and the temperature was decreased to $18^{\circ} \mathrm{C}$. pColdI-His-full 2 recombinant cells grown for 4-6 hours (corresponding to an $\mathrm{OD}_{600 \mathrm{~nm}}$ of 2) were added of $0.1 \mathrm{mM}$ IPTG and $25 \mathrm{~g} / \mathrm{L} \mathrm{NaCl}$ and the temperature was decreased to $15^{\circ} \mathrm{C}$. After 16 hours, cells were harvested by centrifugation, washed with STE buffer and stored at $-20^{\circ} \mathrm{C}$.

\section{Crude extract preparation and purification of fusion proteins}

Cell paste was re-suspended in phosphate buffer saline (PBS) (8.1 mM Na $2 \mathrm{HPO}_{4}, 1.76 \mathrm{mM} \mathrm{KH_{2 }} \mathrm{PO}_{4}, 0.137 \mathrm{M}$ $\mathrm{NaCl}, 2.68 \mathrm{mM} \mathrm{KCl}), \mathrm{pH}$ 7.0, $1 \mathrm{mM}$ phenylmethanesulphonylfluride (PMSF), $10 \mu \mathrm{g} / \mathrm{mL}$ deoxyribonuclease. Cells were disrupted by sonication (5 cycles of $30 \mathrm{~s}$ each, in ice, with 30-s interval). The insoluble fraction was removed by centrifugation at $39000 \times g$ for 1 hour at $4^{\circ} \mathrm{C}$. The crude extract (added of $0.9 \mathrm{M} \mathrm{NaCl}$ ) was loaded on a HiTrap Chelating column (GE Healthcare, Piscataway, NJ, USA), pre-loaded with $\mathrm{Ni}^{2+}$ and equilibrated in PBS, $0.9 \mathrm{M} \mathrm{NaCl}$, $\mathrm{pH}$ 7.0. Elution of the fusion protein was performed increasing the amount of PBS buffer containing $0.5 \mathrm{M}$ imidazole, $\mathrm{pH} 7.0$ [22]. The pure proteins were then equilibrated in $20 \mathrm{mM}$ TrisHCl, $50 \mathrm{mM} \mathrm{NaCl}, \mathrm{pH} 7.4$ by size-exclusion chromatography on a PD10 desalting column or by extensive dialysis.

\section{Enterokinase cleavage of the fusion proteins}

Enterokinases (EK, Recombinant Enterokinase, and Tag • off High Activity Recombinant Enterokinase) and Recombinant Enterokinase Capture Agarose were purchased from Novagen. One EK unit is defined as the amount of enzyme that cleaves $50 \mu \mathrm{g}$ of a control protein (supplied by the producer) in 16 hours at room temperature and in $20 \mathrm{mM}$ TrisHCl, $50 \mathrm{mM} \mathrm{NaCl}, 2 \mathrm{mM} \mathrm{CaCl}_{2}, \mathrm{pH}$ 7.4.

\section{SDS-PAGE electrophoresis and Western blot analysis}

Proteins from total cell extracts or from both soluble and insoluble cell fractions were separated by SDSPAGE: gels were stained for proteins with Coomassie Blue R-250. For total cell extracts and for insoluble fractions after cell disruption, cell pellets were directly resuspended in an appropriate volume of Laemmli sample buffer. For Western blot analysis, upon separation by SDS-PAGE, proteins were transferred electrophoretically onto a nitrocellulose membrane. The fusion proteins were detected using anti-His-tag mouse monoclonal antibody (His-probe, Santa Cruz Biotechnology, Santa
Cruz, CA, USA), rabbit anti-TB10.4 polyclonal antibodies (Antibodies-online $\mathrm{GmbH}$, Aachen, Germany), or rabbit anti-Ag85B polyclonal antibody (DIATHEVA, Fano, Italy), in combination with the appropriate secondary antibody: goat anti-mouse (Santa Cruz Biotechnology, Santa Cruz, CA, USA), donkey anti-mouse and donkey anti-rabbit (Jackson ImmunoResearch Laboratories Inc., West Grove, PA, USA) IgG HRP-conjugated antibody. The immunorecognition was detected by a chemioluminescence method (ECL Plus Western Blotting Detection System, GE Healthcare, Piscataway, NJ, USA). The amount of protein was estimated by evaluating the intensity of the signal using the public domain, Java-based image processing program ImageJ (National Institutes of Health, http://rsb.info.nih. gov/ij/). His-tagged D-amino acid oxidase [23] was used as standard.

\section{Spectral measurements}

Extinction coefficients of native proteins were determined using a Jasco V-560 spectrophotometer by complete denaturation of appropriate dilutions of protein samples in $6 \mathrm{M}$ urea assuming as extinction coefficients of the fully denatured proteins those calculated by ExPASy Bioinformatic Resource Portal (http://www.expasy.org/) using ProtParam tool [24].

Circular dicroism (CD) spectra were recorded on a J815 Jasco spectropolarimeter [24]: cell path-lenth was $1 \mathrm{~cm}$ for measurements above $250 \mathrm{~nm}(0.4 \mathrm{mg}$ protein/ $\mathrm{mL})$ and $0.1 \mathrm{~cm}$ for measurements in the 190-250 nm range $(0.1 \mathrm{mg}$ protein $/ \mathrm{mL})$. Secondary structure fractions were calculated from deconvolution of the CD spectra with the program K2D2 (http://www.ogic.ca/projects/k2d2/) [25].

Temperature ramp experiments were carried out by using the same instrumentation equipped with a softwaredriven Peltier-based temperature controller (temperature gradient: $0.5^{\circ} \mathrm{C} / \mathrm{min}$ ). All spectral experiments were carried out in $20 \mathrm{mM}$ MOPS, $0.4 \mathrm{M} \mathrm{NaCl}, \mathrm{pH} 7.0$ or in $10 \mathrm{mM}$ ammonium acetate, $\mathrm{pH} 7.0$ at $15^{\circ} \mathrm{C}$.

\section{Mass spectrometry analyses}

Intact MS experiments were in general carried out on a LTQ-MS (Thermo Electron, San Jose, CA, USA) with an ESI source. The protein samples were prepared in $10 \mathrm{mM}$ ammonium bicarbonate ( $\mathrm{pH} 7.4), 0.1 \%$ acetonitrile/trifluroacetic acid (50/50) to a final concentration of $0.3 \mathrm{mg} / \mathrm{mL}$. Full scan intact MS experiments were carried out under the following instrumental conditions: positive ion mode, mass range $700-2000 \mathrm{~m} / \mathrm{z}$, source voltage $4.5 \mathrm{kV}$, capillary voltage $35 \mathrm{~V}$, sheat gas 15 , auxiliary gas 2 , capillary temperature $220^{\circ} \mathrm{C}$, tube lens voltage $140 \mathrm{~V}$. Five spectra were acquired for each data and each spectrum was the composite of two averaged scans. Data processing was performed using Bioworks Browser (Thermo Electron, 
revision 3.1). Theoretical average masses were calculated by Ion Source Bioinformatic Resource Portal (http://www. ionsource.com/) using Peptide Mass Calculator tool. Identification of truncated forms of the proteins was carried out by MS-non specific database search program Protein Prospector v 5.10.4 (http://prospector.ucsf.edu).

The His-full2 protein was dissolved in acetonitrile and analyzed using a MALDI-TOF/TOF Ultraflex III spectrometer (Bruker Daltonics, Bremen, Germany) in linear positive mode. A solution of sinapinic acid (SA) $20 \mathrm{mg} / \mathrm{mL}$ solved in a 70/30 acetonitrile/trifluoroacetic acid (TFA) $0.1 \%$ solution, was used as matrix. The spectra were acquired in a mass range of $6000-52000 \mathrm{~m} / \mathrm{z}$ and processed using Flex Analysis software 3.0 (Bruker Daltonics).

\section{Immunological studies: study population}

The study population included 19 subjects. Twelve patients with newly diagnosed, untreated active pulmonary TB and 7 healthy individuals without any history of TB exposure (hereafter indicated as TB unexposed controls). Study subjects were recruited at the Department of Infectious Diseases of the Fondazione IRCCS-Policlinico San Matteo of Pavia (Italy), after informed consent. In all cases, the diagnosis of active TB was confirmed by $M$. tuberculosis culture isolation.

Peripheral venous blood was obtained for serum samples from all the participants to the study to perform ELISA assay. Additionally, peripheral blood was collected into tubes containing heparin for ELISPOT assay. Peripheral blood mononuclear cells (PBMC) were isolated by standard density gradient centrifugation using Lymphoprep (Axis-Shield, Oslo, Norway). Isolated PBMC were cryopreserved in freezing medium: 10\% v/v DMSO (SigmaAldrich, St. Louis, MO, USA), 25\% v/v human albumin (Grifolds Biologicals, Los Angeles, CA, USA) and 65\% v/v RPMI 1640 supplemented with $2 \mathrm{mM}$ L-glutamine, $100 \mathrm{U} / \mathrm{mL}$ penicillin and $100 \mu \mathrm{g} / \mathrm{mL}$ streptomycin (all from Euroclone, Milan, Italy) and kept in liquid nitrogen until ELISPOT analyses.

\section{ELISA assay}

ELISA assay was performed with the method of [26] with minor modifications. Microplates 96-wells highbinding capacity flat-bottom (Greiner-bio-one $\mathrm{GmbH}$, Frickenhausen Germany) were coated with different concentrations (400, 200, $100 \mathrm{ng} /$ well) of Ag85B, TB10.4, Hisfull2 in $50 \mathrm{mM}$ bicarbonate buffer ( $\mathrm{pH} 9.6)$ and incubated at room temperature overnight. Plates were washed three times with $0.05 \%(\mathrm{v} / \mathrm{v})$ Tween-20 in phosphate buffered saline (PBS-T, Sigma-Aldrich, St. Louis, MO, USA) and incubated with $200 \mu \mathrm{L} /$ well of blocking buffer (PBS with $1 \%$ BSA) at room temperature for at least 1 hour and then washed three times with PBS-T. Serum samples were diluted with dilution buffer (PBS-T with 1\% BSA) at scalar dilution of 1:50 to 1:800. One-hundred microliter of the diluted sera was added to each well and incubated for 1 hour at $37^{\circ} \mathrm{C}$. Plates were then washed four times with PBS-T. Anti-human specific IgG antibody labeled with horseradish peroxidase (MP Biomedicals, LLC Santa Ana, CA, USA) was added to each well and incubated at $37^{\circ} \mathrm{C}$ for 1 hour. Plates were again washed four times with PBS-T and $100 \mu \mathrm{L}$ of o-phenyl-diamine $/ \mathrm{H}_{2} \mathrm{O}_{2}$ substrate (Sigma-Aldrich, St. Louis, MO, USA) was added for $30 \mathrm{mi}-$ nutes. The reaction was stopped by adding $50 \mu \mathrm{L}$ of $0.5 \mathrm{M}$ $\mathrm{H}_{2} \mathrm{SO}_{4}$. The absorbance at $492 \mathrm{~nm}$ was measured with an ELISA plate spectrophotometer (Titertek Plus MS212 ICN, Eschwege, Germany).

\section{Evaluation of peptide specific single T-cell IFN- $\gamma$ release}

The enumeration of peptide specific $\mathrm{T}$-cell producing IFN- $\gamma$ was performed at the single cell level by using ELISPOT assay, as previously described, with minor modifications [27].

In detail, PBMC were thawed, washed and re-suspended in the culture medium: RPMI 1640 medium supplemented with $2 \mathrm{mM}$ L-glutamine, $100 \mathrm{U} / \mathrm{mL}$ penicillin, $100 \mu \mathrm{g} / \mathrm{mL}$ streptomycin and 10\% heat-inactivated fetal calf serum (Euroclone, Milan, Italy). Cells were kept overnight at $37^{\circ} \mathrm{C}$ in a humidified $5 \% \mathrm{CO}_{2}$ atmosphere. Cells were then transferred to a 24-well flat-bottom plate $\left(5 \times 10^{5}\right.$ cells $/ \mathrm{mL}$ per well), stimulated with $1 \mu \mathrm{g} / \mathrm{mL}$ of each protein (one protein per well) or culture medium only or phytohemagglutinin (PHA) $(5 \mu \mathrm{g} / \mathrm{mL}$; SigmaAldrich, St. Louis, MO, USA), and cultured at $37^{\circ} \mathrm{C}$ in a humidified $5 \% \mathrm{CO}_{2}$ atmosphere for 10 days. On days 3 and 7 , half of the supernatant from each well was removed and replaced with wet culture medium supplemented with $20 \mathrm{IU} / \mathrm{mL}$ recombinant human IL-2 (Peprotech, London, UK). After 10 days, cells from each well were harvested, washed three times with culture medium and resuspended at a concentration of $4 \times 10^{5}$ cells $/ \mathrm{mL}$ before their use in ELISPOT assay. Un-stimulated PBMC were included as negative controls.

In ELISPOT assay, multiScreen-IP 96-well plates (Merck Millipore, Darmstadt, Germany) were coated with IFN- $\gamma$ capture antibody and incubated overnight at $4^{\circ} \mathrm{C}$. Plates were then washed 5 times with PBS and blocked with culture medium for 2 hours at room temperature. Antigen-stimulated cells for 10 days were added in duplicate $\left(4 \times 10^{4}\right.$ cells/well $)$ and re-stimulated with each protein used for stimulation during the 10-day period. Cells stimulated with PHA during the 10-day period were re-stimulated with Staphylococcus aureus Enterotoxin B (SEB) superantigen (2 $\mu \mathrm{g} / \mathrm{mL}$; SigmaAldrich, St. Louis, MO, USA). After incubation at $37^{\circ} \mathrm{C}$ in a humidified $5 \% \mathrm{CO}_{2}$ atmosphere for 24 hours, plates were washed five times with PBS-T (Sigma-Aldrich, St. Louis, MO, USA). Biotinylated detection antibody for 
IFN- $\gamma$ was added and incubated overnight at $4^{\circ} \mathrm{C}$. After five washes with PBS-T, streptavidin-alkaline phosphatase conjugate was added and plates were incubated at $37^{\circ} \mathrm{C}$, $5 \% \mathrm{CO}_{2}$ atmosphere for 1 hour. Plates were then washed, 5-bromo-4-chloro-3-indolyl-phosphate/nitro blue tetrazolium (BCIP/NBT) was added and incubated at room temperature for 20 minutes. Wells were then washed several times under running water and air-dried. Spotforming cells (SFCs) were counted in duplicate wells using an automated ELISPOT reader system (Autoimmun Diagnostika $\mathrm{GmbH}$, Strassberg, Germany). The mean value of the SFCs was calculated, and the value of the control subtracted to the SFCs of the stimuli: values were referred to million PBMC.

\section{Statistical analysis}

Data are expressed using mean and standard deviation of the mean or median and percentiles as appropriate. Comparison between groups have been made using Mann-Whitney and $x^{2}$ tests. A $p$ value below 0.05 was considered significant. All tests were performed using the GraphPad Prism 4.0 (Graphpad software, San Diego, CA, USA) software package.

\section{Additional files}

Additional file 1: Nucleotide and amino acid sequences of antigenic proteins.

Additional file 2: Expression and purification of antigenic proteins.

Additional file 3: Immunological assays.

\section{Competing interests}

The authors declare that they have no competing interests.

\section{Author's contributions}

LuP and MC cloned, expressed and purified the chimeric proteins. CT and MT developed the analytical methods for protein identity and purity. EB and FIM carried out experiments at fermenter scale. FrM and MA performed the immunological assays and analyzed the data. FIM and LoP co-wrote the paper. LoP supervised the protein biochemistry experiments and conceived the project. All authors have read and approved the final manuscript.

\section{Acknowledgments}

This work was supported by grants from Regione Lombardia Progetto VATUB (Approccio biotecnologico alla progettazione razionale di vaccini: nuovo vaccino anti TB -Progetto finanziato da Regione Lombardia nell'ambito dell'Accordo Quadro di collaborazione con le Università lombarde DGR n. 9139 del 30/03/2009 e n. 9565 del 11/06/2009) and Fondo di Ateneo per la Ricerca (University of Insubria) to L. Pollegioni, L. Piubelli and F. Marinelli. We thank G. Molla (DBSV, University of Insubria) for help in designing chimeric recombinant proteins and L. Caldinelli (DBSV, University of Insubria) for CD measurements. Authors also acknowledge G. Pieraccini and F. Boscaro (Mass Spectrometry Centre, University of Florence) for MALDI-TOF/TOF experiments, V. Monzillo and S. Calarota (Fondazione IRCCS-Policlinico San Matteo) for support in ex-vivo biological evaluation of recombinant proteins, and A. Sarasini (Fondazione IRCCS-Policlinico San Matteo) for collaboration in ELISA assays.

\section{Author details}

'Department of Biotechnology and Life Sciences, University of Insubria, Varese, Italy. ${ }^{2}$ The Protein Factory, Interuniversity Centre Politecnico di Milano, ICRM CNR Milano and University of Insubria, Milan, Italy. ${ }^{3}$ Department of Drug Sciences and Italian Biocatalysis Centre, University of Pavia, Pavia, Italy. ${ }^{4}$ Department of Infection Diseases, Fondazione IRCCS-Policlinico San Matteo, Pavia, Italy. ${ }^{5}$ Department of Biomedicine and Prevention, University of Rome Tor Vergata, Rome, Italy. ${ }^{6}$ ProxAgen Ltd., Sofia, Bulgaria. ${ }^{7}$ Present address: Foundation Edmund Mach, San Michele all'Adige, Trento, Italy.

Received: 8 August 2013 Accepted: 14 November 2013

Published: 19 November 2013

\section{References}

1. World Health Organization: Global tuberculosis control. WHO Report. Geneva, Switzerland: WHO Press; 2011

2. Flynn JL, Chan J: Immunology of tuberculosis. Annu Rev Immunol 2001, 19:93-129.

3. Colditz GA, Brewer TF, Berkey CS, Wilson ME, Burdick E, Fineberg HV, Mosteller F: Efficacy of BCG vaccine in the prevention of tuberculosis. Meta-analysis of the published literature. JAMA 1994, 71:698-702.

4. Trunz BB, Fine P, Dye C: Effect of BCG vaccination on childhood tuberculous meningitis and miliary tuberculosis worldwide: a meta-analysis and assessment of cost-effectiveness. Lancet 2006, 367:1173-1180.

5. Anand P, Sankaran S, Mukherjee S, Yeturu K, Laskowski R, Bhardwaj A, Bhagavat R, Brahmachari SK, Chandra N N, OSDD Consortium: Structural annotation of Mycobacterium tuberculosis proteome. PLoS One 2011, 6(10):e27044.

6. Dietrich J, Aagaard C, Leah R, Olsen AW, Stryhn A, Doherty TM, Andersen P. Exchanging ESAT6 with TB10.4 in an Ag85B fusion molecule-based tuberculosis subunit vaccine: efficient protection and ESAT6-based sensitive monitoring of vaccine efficacy. J Immunol 2005, 174:6332-6339

7. Aagaard C, Hoang T, Dietrich J, Cardona PJ, Izzo A, Dolganov G, Schoolnik GK, Cassidy JP, Billeskov R, Andersen P: A multistage tuberculosis vaccine that confers efficient protection before and after exposure. Nat Med 2011, 17:189-194.

8. Skjøt RL, Oettinger T, Rosenkrands I, Ravn P, Brock I, Jacobsen S, Andersen P: Comparative evaluation of low-molecular-mass proteins from Mycobacterium tuberculosis identifies members of the ESAT-6 family as immunodominant T-cell antigens. Infect Immun 2000, 68:214-220.

9. Jong WSP, Soprova Z, de Punder K, ten Hagen-Jongman CM, Wagner S, Wickström D, de Gier JW, Andersen P, van der Wel NN, Luirink J: A structurally informed autotrasporter platform for efficient heterologous protein secretion and display. Microb Cell Fact 2012, 11:85.

10. Ihssen J, Kowarik M, Dilettoso S, Tanner C, Wacker M, Thöny-Meyer L: Production of glycoprotein vaccines in Escherichia coli. Microb Cell Fact 2010, 9:61

11. Waegeman $\mathrm{H}$, Soetaert W: Increasing recombinant protein production in Escherichia coli through metabolic and genetic engineering. I Ind Microbiol Biotechnol 2011, 38:1891-1910.

12. Shi S, Yu L, Sun D, Liu J, Hickey AJ: Rational design of multiple TB antigens TB10.4 and TB10.4-Ag85B as subunit vaccine candidates against Mycobacterium tuberculosis. Pharm Res 2009, 27:224-234.

13. La Vallie ER, Di Blasio EA, Kovacic S, Grant KL, Schendel PF, McCoy JM: A thioredoxin gene fusion expression system that circumvents inclusion body formation in the E. coli cytoplasm. Biotech 1993, 11:187-193.

14. Qing G, Ma LC, Khorchid A, Swapna GVT, Mal TK, Takayama MM, Xia B, Phadtare S, Ke H, Acton T, Montelione GT, Ikura M, Inouye M: Cold-shock induced high-yield protein production in Escherichia coli. Nat Biotech 2004, 22:877-882.

15. Volontè F, Marinelli F, Gastaldo L, Sacchi S, Pilone MS, Pollegioni L, Molla G: Optimization of glutaryl-7-aminocephalosporanic acid acylase expression in E. coli. Protein Expr Purif 2008, 61:131-137.

16. Ottenhoff $\mathrm{TH}$, Kaufmann $\mathrm{SH}$ : Vaccines against tuberculosis: where are we and where do we need to go? PloS Pathog 2012, 8:e1002607.

17. Dormitzer PR, Grandi G, Rappuoli R: Structural vaccinology starts to deliver. Nat Rev Microbiol 2012, 10:807-813.

18. Lakey DL, Voladri RK, Edwards KM, Hager C, Samten B, Wallis RS, et al: Enhanced production of recombinant Mycobacterium tuberculosis 
antigens in Escherichia coli by replacement of low-usage codons. Infect Immun 2002, 68:233-238.

19. Skjot RL, Brock I, Arend SM, Munk ME, Theisen M, Ottenhoff TH, et al: Epitope mapping of the immunodominant antigen TB10.4 and the two homologous proteins TB10.3 and TB12.9, which constitute a subfamily of the esat- 6 gene family. Infect Immun 2002, 70:5446-5453.

20. Volontè F, Pollegioni L, Molla G, Frattini L, Marinelli F, Piubelli L: Production of recombinant cholesterol oxidase containing covalently bound FAD in Escherichia coli. BMC Biotechnol 2010, 21:10-33.

21. Romano D, Molla G, Pollegioni L, Marinelli F: Optimization of human D-amino acid oxidase expression in Escherichia coli. Protein Expr Purif 2009, 68:72-78.

22. Molla G, Bernasconi M, Sacchi S, Pilone MS, Pollegioni L: Expression in Escherichia coli and in vitro refolding of the human protein pLG72. Protein Expr Purif 2006, 46:150-155.

23. Fantinato S, Pollegioni L, Pilone MS: Engineering, expression and purification of a His-tagged chimeric D-amino acid oxidase from Rhodotorula gracilis. Enzyme Microb Technol 2005, 29:407-412.

24. Caldinelli L, lametti S, Barbiroli A, Bonomi F, Fessas D, Molla G, Pilone MS, Pollegioni L: Dissecting the structural determinants of the stability of cholesterol oxidase containing covalently bound flavin. J Biol Chem 2005, 280:22572-22581.

25. Perez-Iratxeta C, Andrade-Navarro MA: K2D2: estimation of protein secondary structure from circular dichroism spectra. BMC Struct Biol 2008, $8: 25-29$.

26. Rajpal SK, Seema DS, Amit R, Hemant J, Girdhar MT, Hatim FD: Diagnosis of tuberculosis infection based on synthetic peptides from Mycobacterium tuberculosis antigen 85 complex. Clin Neurol Neurosurg 2013, 115:678-683.

27. Calarota SA, Foli A, Maserati R, Baldanti F, Paolucci S, Young MA, Tsoukas CM, Lisziewicz J, Lori F: HIV-1-specific T cell precursors with high proliferative capacity correlate with low viremia and high CD4 counts in untreated individuals. J Immunol 2008, 180:5907-5915.

doi:10.1186/1475-2859-12-115

Cite this article as: Piubelli et al:: Optimizing Escherichia coli as a protein expression platform to produce Mycobacterium tuberculosis immunogenic proteins. Microbial Cell Factories 2013 12:115.

\section{Submit your next manuscript to BioMed Central and take full advantage of:}

- Convenient online submission

- Thorough peer review

- No space constraints or color figure charges

- Immediate publication on acceptance

- Inclusion in PubMed, CAS, Scopus and Google Scholar

- Research which is freely available for redistribution 